\title{
Biotechnology in gold processing
}

\author{
K A NATARAJAN \\ Department of Metallurgy, Indian Institute of Science, Bangalore 560012, India
}

\begin{abstract}
The applicability of a biotechnological approach for extracting gold from lean grade and refractory ores and from tailings is analysed. Microbiological as well as physicochemical characteristics of various leaching bacteria are outlined. Technological aspects of bioleaching of refractory gold-bearing concentrates in specially designed bioreactors are illustrated with emphasis on control parameters and use of metal and temperature-tolerant strains. Commercial operations prevalent across the world are detailed and the relevance of biomineral technology for augmentation of gold production in India brought out.
\end{abstract}

Keywords. Bioleaching; Thiobacillus ferrooxidans; refractory gold ores; bioreactors; biosorption; biodegradation.

\section{Introduction}

Gold usually occurs in elemental form or alloyed with silver in association with other minerals. Depending on mineralogical associations, different types of natural gold occurrences are possible. Free milling ores are those in which the precious metal occurs disseminated in the host rock (mostly quartzite) and could be directly subjected to cyanidation after appropriate size reduction. In refractory ores, gold particles essentially remain encapsulated in a sulphide matrix or associated with carbonaceous matter. Conventional techniques such as cyanide leaching would not yield the required gold recovery from such refractory ores. Several possible methods could be adopted to liberate the finely disseminated gold particles from such encapsulated mineral matrices before they could be cyanided for efficient recovery. Processes such as roasting, matte or plasma smelting, pressure leaching or pressure cyanidation as well as hot digestion in mineral acids, though technologically feasible, pose severe environmental and corrosion problems in practice coupled with higher costs and energy consumption. A bioprocessing approach, on the other hand, could prove to be economically and environmentally advantageous.

Bioprocessing has the following industrial applications with reference to gold extraction (Karavaiko and Groudev 1985; Lawrence 1990): (a) Biooxidation of refractory gold-bearing sulphides by chemolithotrophic bacteria to liberate encapsulated gold before cyanidation. (b) Direct gold solubilization by heterotrophic organisms. (c) Recovery of gold from leach and effluent solutions through biosorption. (d) Biodegradation of cyanide wastes and bioenvironmental control. In this article, applicability of biotechnology in the extractive metallurgy of gold is analysed with respect to microbiological aspects, bioleaching mechanisms, process control, industrial processes and future trends. The urgent need to adopt this technology to augment gold production in India is also brought out. 


\section{Leaching organisms}

Depending on the type of the ore or concentrate to be leached, the nature of the bacteria to be used in the process also differs. For liberation of locked-up gold particles from sulphide minerals such as pyrite, arsenopyrite, pyrrhotite and chalcopyrite, prior bacterial treatment with Thiobacillus ferrooxidans, Thiobacillus thiooxidans and Leptospirillum ferrooxidans will be very beneficial. A mineralogical photograph showing gold particles disseminated in pyrite and arsenopyrite grains is shown in figure 1. Moderately thermophilic organisms, mixed cultures as well as thermophilic strains such as Sulfolobus enable faster leaching of the sulphide minerals (Hutchins et al 1988; Komnitsas and Pooley 1990; Torma 1992). Among the above organisms, Thiobacillus ferrooxidans is the most widely implicated bacterium in the leaching of gold-bearing sulphides. It is a motile, monoflagellated, nonspore forming, gramnegative, rod-shaped $(0.5$ to $1.5 \mu \mathrm{m})$, aerobic, acidophilic mesophile, obtaining its energy for metabolism through the oxidation of reduced-valence sulphur compounds and ferrous iron. The optimum $\mathrm{pH}$ for their growth is about 2.3 at a temperature of about $30-35^{\circ} \mathrm{C}$. Pyrite and arsenopyrite are readily oxidised by the bacteria to yield acidic ferric sulphate.

$$
\begin{aligned}
& 4 \mathrm{FeAsS}+13 \mathrm{O}_{2}+6 \mathrm{H}_{2} \mathrm{O} \stackrel{\text { bacteria }}{\longrightarrow} 4 \mathrm{H}_{3} \mathrm{AsO}_{4}+\mathrm{FeSO}_{4}, \\
& 2 \mathrm{FeS}_{2}+7 \mathrm{O}_{2}+2 \mathrm{H}_{2} \mathrm{O} \stackrel{\text { bacteria }}{\longrightarrow} 2 \mathrm{FeSO}_{4}+2 \mathrm{H}_{2} \mathrm{SO}_{4},
\end{aligned}
$$

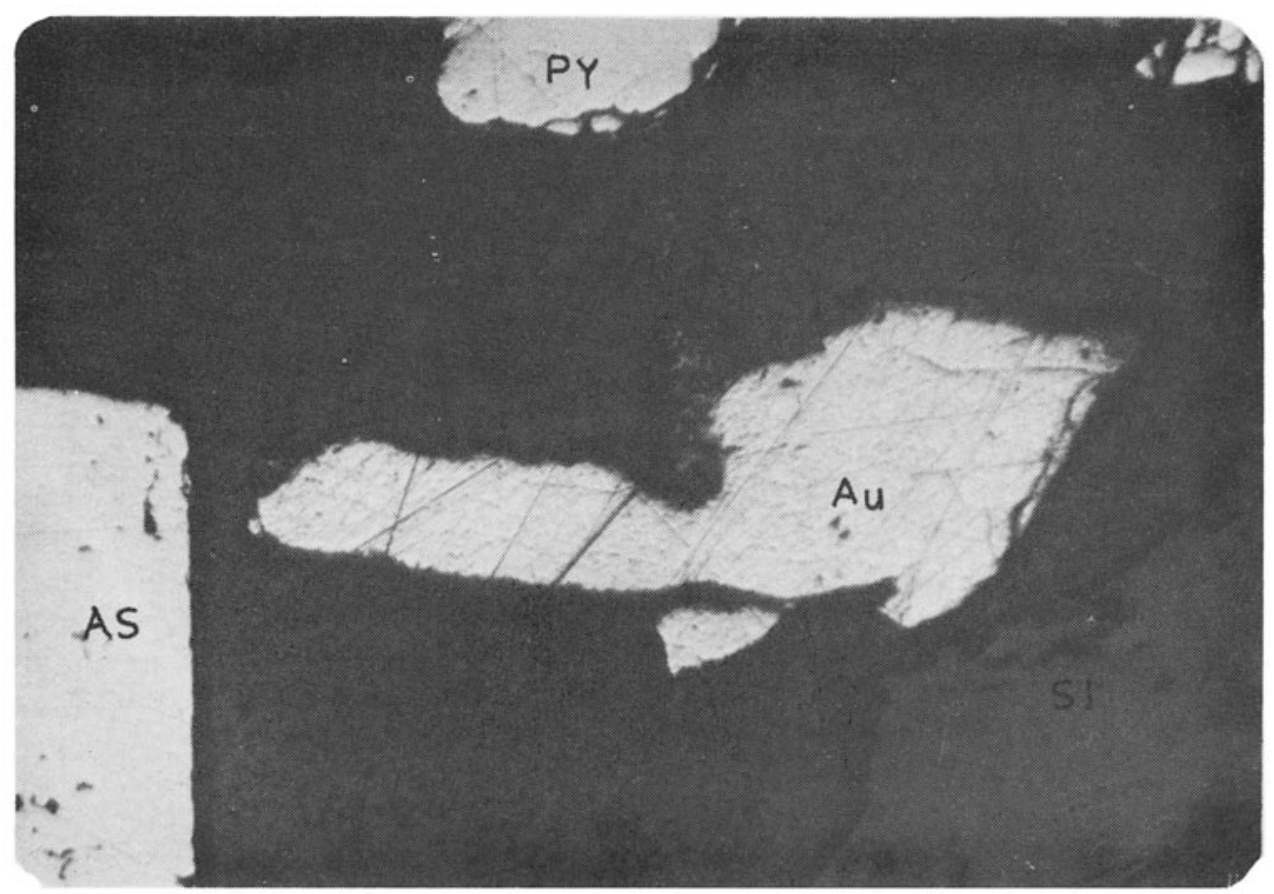

Figure 1. Mineralogical photograph illustrating gold ( $\mathrm{Au}$ ) particles disseminated in pyrite (Py) and arsenopyrite (As). 

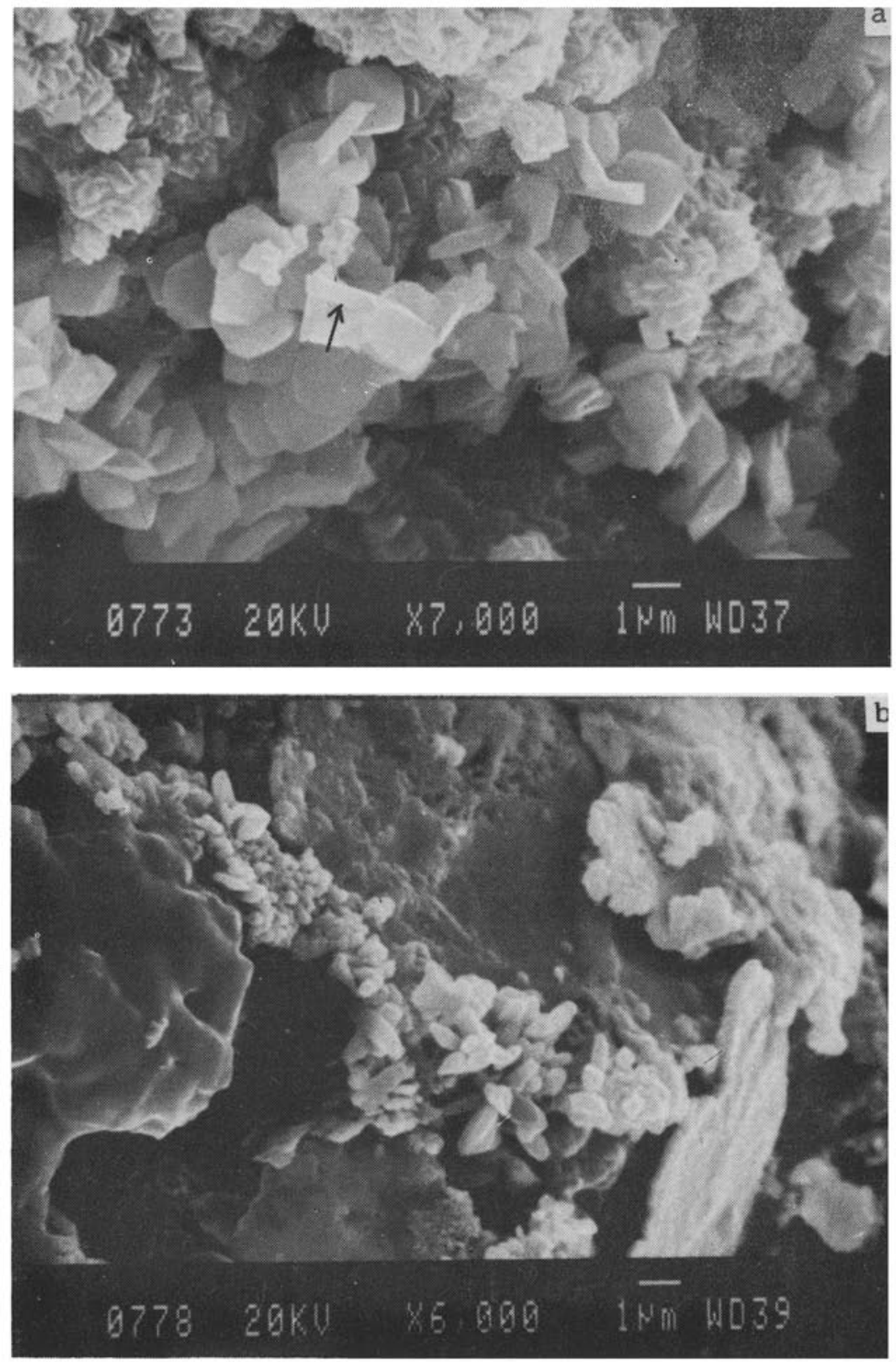

Figure 2. Thiobacillus ferrooxidans adhering to pyrite and chalcopyrite mineral phases in a gold ore. Morphology of a bioleached surface is shown in the below photograph. 


$$
\begin{aligned}
& 4 \mathrm{FeSO}_{4}+\mathrm{O}_{2}+2 \mathrm{H}_{2} \mathrm{SO}_{4} \stackrel{\text { bacteria }}{\longrightarrow} 2 \mathrm{Fe}_{2}\left(\mathrm{SO}_{4}\right)_{3}+2 \mathrm{H}_{2} \mathrm{O} \\
& 2 \mathrm{FeAsS}+\mathrm{Fe}_{2}\left(\mathrm{SO}_{4}\right)_{3}+6 \mathrm{O}_{2}+4 \mathrm{H}_{2} \mathrm{O} \rightarrow 2 \mathrm{H}_{3} \mathrm{AsO}_{4}+4 \mathrm{FeSO}_{4}+\mathrm{H}_{2} \mathrm{SO}_{4}, \\
& 2 \mathrm{H}_{3} \mathrm{AsO}_{4}+\mathrm{Fe}_{2}\left(\mathrm{SO}_{4}\right)_{3} \rightarrow 2 \mathrm{FeAsO}_{4}+3 \mathrm{H}_{2} \mathrm{SO}_{4} \\
& \mathrm{FeS}_{2}+\mathrm{Fe}_{2}\left(\mathrm{SO}_{4}\right)_{3} \rightarrow 3 \mathrm{FeSO}_{4}+2 \mathrm{~S}^{\circ} \\
& \quad 2 \mathrm{~S}^{\circ}+2 \mathrm{H}_{2} \mathrm{O}+3 \mathrm{O}_{2} \stackrel{\text { bacteria }}{\longrightarrow} 2 \mathrm{H}_{2} \mathrm{SO}_{4}
\end{aligned}
$$

The manner in which Thiobacillus ferrooxidans attach themselves to pyrite and chalcopyrite minerals in a gold ore is illustrated in figure 2 along with the morphology of the leached surface.

As the bacteria help in dissolving away the sulphide minerals, gold particles are liberated in the process, enabling subsequent cyanidation.

$$
2 \mathrm{Au}+4 \mathrm{NaCN}+\mathrm{O}_{2}+2 \mathrm{H}_{2} \mathrm{O} \rightarrow 2 \mathrm{NaAu}(\mathrm{CN})_{2}+2 \mathrm{NaOH}+2 \mathrm{H}_{2} \mathrm{O}_{2}
$$

Thus, biotreatment of gold-bearing sulphides using autotrophic bacteria as above is essentially a pretreatment step and could easily be incorporated in existing plant flow sheets.

For direct gold solubilization from lateritic and quartzitic gold ores, different heterotrophic bacteria could be used. Bacteria of the genus Aeromonas can solubilize gold

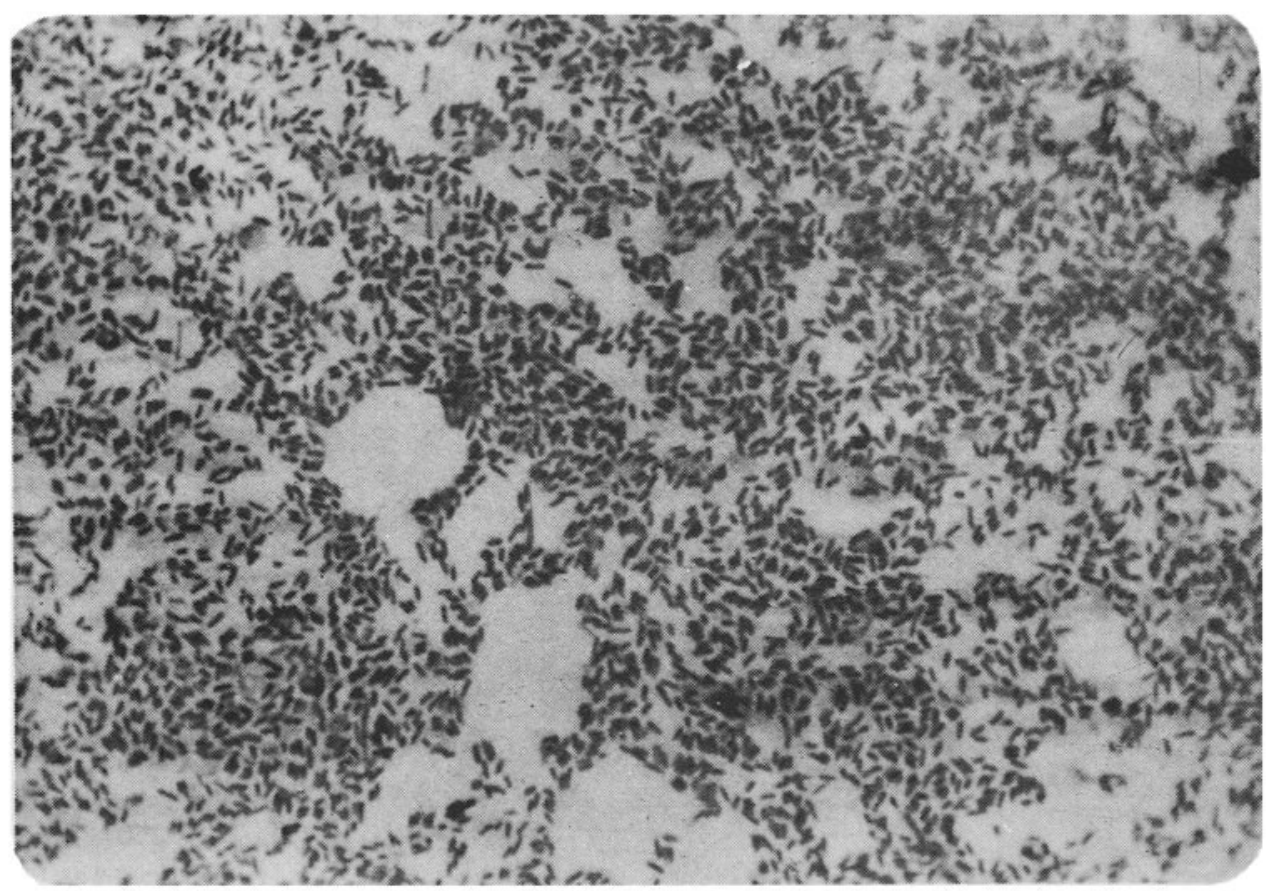

Figure 3. Optical micrograph $(600 \times)$ of Bacillus subtilis, a direct gold solubilising microbe. 
at an alkaline $\mathrm{pH}$ of $8-8 \cdot 5$. Other gold-solubilizing bacteria such as Bacillus subtilis, Bacillus mesentericus and Bacillus sp. occur in many ore deposits. These organisms essentially secrete gold-solubilizing peroxides and amino acids. Protein hydrolysates obtained after alkaline hydrolysis of protein-rich substances such as mycelium of the fungus, Aspergillus niger could also effectively solubilize gold (Natarajan 1992). A direct gold-solubilizing organism, Bacillus subtilis is shown as a microphotograph in figure 3.

\section{Bioreactor technology}

Biotreatment of refractory gold-bearing sulphides using Thiobacillus ferrooxidans has been commercially practised the world over. The following essential steps are involved: (a) Comminution - grinding to finer sizes of $40-70 \mu \mathrm{m}$. (b) Flotation beneficiation to yield gold-enriched sulphide concentrates. (c) Reactor bioleaching of concentrates under controlled conditions. (d) Solid-liquid separation. (e) Lime treatment of bioleached residues and cyanide leaching. (f) Gold recovery from cyanide leach liquor.

During bioleaching of the concentrates, the following parameters need be controlled.

Temperature $30-35^{\circ} \mathrm{C}$

pH 1.7-2

Nutrients $9 \mathrm{~K}$ concentration

Availability of $\mathrm{O}_{2}$ and $\mathrm{CO}_{2}$ (air)

Arsenic tolerance

Controlled agitation of slurry

Solid-liquid ratio in the range $10-20 \%$

Continuous removal of ferric and other reaction products

Recirculation and maintenance of active biomass

Several prototype bioreactor systems have been tested for the purpose (Hackl and Wright 1989; Biomine 1993). A pioneer in this area is the Fairview mine in South Africa which has operated for the past ten years. Others include the Equity silver mine, British Columbia, Canada, BRGM pilot plant in France and the Transworld Mining and Minerals of Australia. All the plants reported thus far employ stirred tank reactors with a capacity ranging between $100 \mathrm{~kg}$ and 120 tons of concentrate per day. Mesophilic organisms are used in most of the plants except a few which use moderately thermophilic bacteria at $45^{\circ} \mathrm{C}$.

Commercial plants are fast coming up. Ashton Mining's Harbour lights operations in Western Australia is one of the largest. Asarco Australia Limited commissioned its flotation and bioleaching reactors very recently at Wiluna, also in Western Australia. About an year ago, Ashanti gold mines in Ghana initiated bioleaching for gold. BacTech (Australia) has developed a moderate thermophilic strain which can operate at a temperature of $40-50^{\circ} \mathrm{C}$. CRA Advanced Technical Development in Melbourne, Australia has focussed its efforts in bioreactor as well as bioheap leaching.

\section{Bioheap leaching}

Heap leaching in the presence of bacteria would be very useful to recover gold from lean grade ores as well as tailings. Considerable amounts of low grade ores (containing 


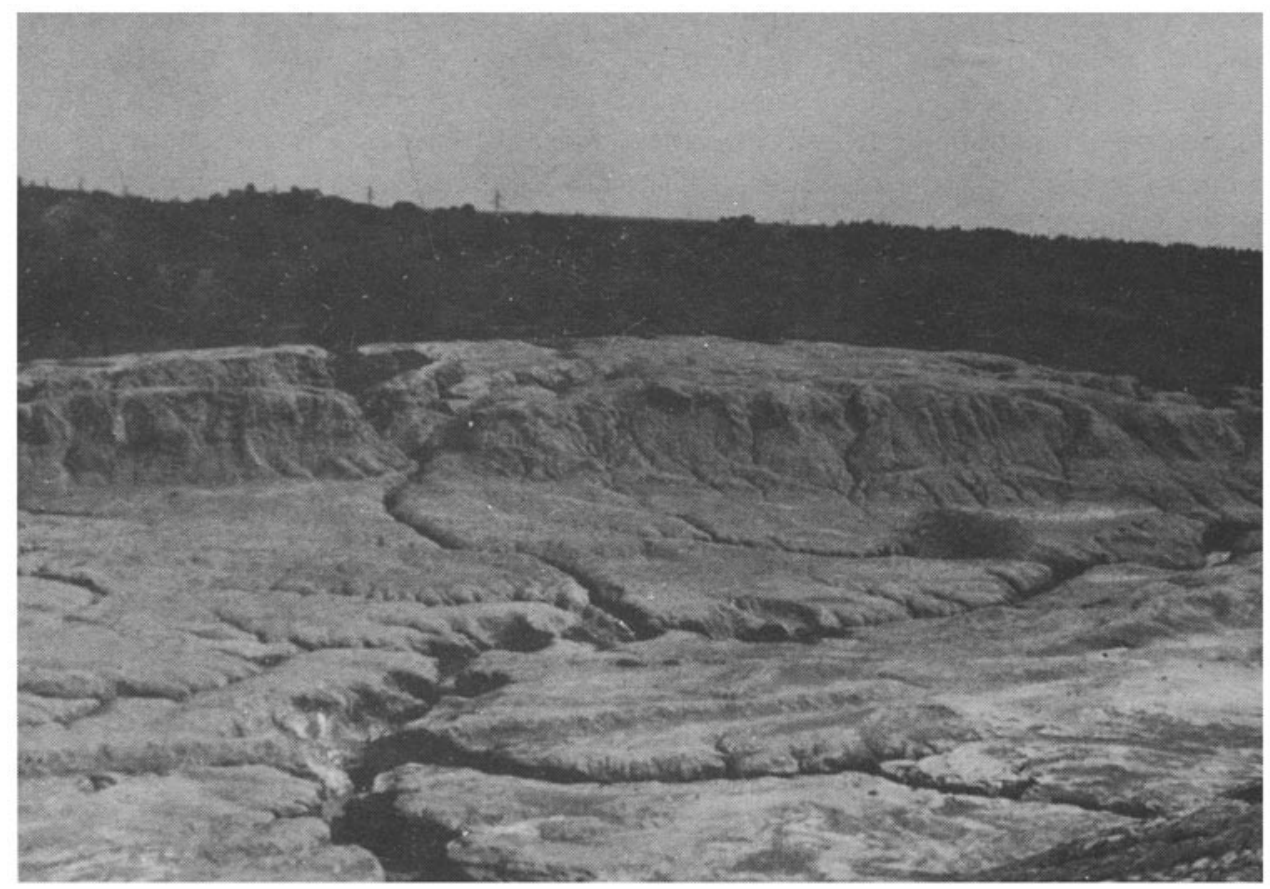

Figure 4. Tailing heap at a mine site.

about $2 \mathrm{~g} /$ ton of gold) exist at different mine sites. Similarly, several millions of tons of tailings have been accumulated in different gold processing plants, containing on an average between 0.2 and $1.0 \mathrm{ppm}$ of gold which are unrecovered during the cyanidation process. Bioleaching in specially prepared or existing heaps would help in recovering the precious metal. Biotreatment of tailings in slime dams has been attempted in South Africa. Tests have demonstrated that plowing up a layer of compacted tailings into loose granular mass to enable air and water permeation and subsequent inoculation of bacteria, would aid the bioliberation of trapped gold particles from the waste dumps. This technology would be cheaper and environmentally safer (Brad Merchant 1986). Figure 4 illustrates a typical tailing heap at a mine site. Gold entrapped in such abandoned heaps can be effectively bioleached.

\section{Biodegradation and biosorption}

Microorganisms, principally bacteria and fungi, immobilize, mobilize or transform metals through a number of mechanisms involving extracellular precipitation, and intracellular accumulation, oxidation and reduction and extracellular binding and complexation. Besides, certain organisms can degrade constituents such as cyanide and processing reagents. Biodegradation of free cyanide is widely reported. Ironcomplexed cyanides could also be biodegraded. This type of technology has been successfully applied at the Homestake Gold Mines in Lead, South Dakota in USA.

Microorganisms can sequester metal ions from solution with their sorption capacity differing depending on the type of the organism. Almost complete removal of gold 
from solutions by algae has been reported. Algae could easily be cultivated in fields adjoining gold plants or harvested from tailing ponds. Sorption of gold and silver complexes by biopolymers such as alginate and chitosan and by algal species of the type, $C$. vulgaris, $C$. pyrenoidosa and $C$. kessleri has been known. Fungi such as Aspergillus niger and Penicillium spinulosum can remove up to $90 \%$ of gold from effluents. Such biosorption processes could be used with advantage to recover precious metals from waste liquors, leach solutions and effluents and achieve environmental control at the same time.

\section{Applicability in India}

Biotechnology holds great promise in India. Current annual metallic gold production in the country is about a meagre 2 tonnes and there is an urgent need not only to augment existing production targets but also to exploit hitherto untapped lean and low grade resources. Refractory gold ores associated with pyrite and arsenopyrite occur in different parts of the country including the Kolar, Raichur and Gadag belts of Karnataka. The existing gold-processing plants at Kolar and Hutti have accumulated several million tonnes of tailings containing unrecovered gold between 0.2 and $1.0 \mathrm{~g} / \mathrm{t}$ and adaptation of biomineral technology could help in the recovery of the precious metal from these waste dumps. Many low tonnage small pockets of gold deposits scattered around the country could be turned into treasure chests through this technology. Recent studies indicate that the gold ore deposits in the country host a variety of microorganisms of relevance to gold extraction. Amenability studies have further proved the suitability of this technology to treat lean grade and refractory ores.

\section{Future trends}

In the bioleaching of gold-bearing sulphides, accumulation of toxic metal ions such as arsenic, copper and zinc hampers bacterial activity. Development of metal-tolerant, preadapted bacterial strains is thus essential to achieve efficient and uninterrupted bacterial activity in a bioreactor. Thiobacillus ferrooxidans strains could be preadapted to sulphide concentrates for prolonged periods before use. Such strains are found to be more efficient in gold liberation compared to unadapted wild strains. Similarly, bacteria could be adapted through serial transfer to tolerate larger concentrations of dissolved arsenic, ferric iron, copper and zinc (Attia and Elzeky 1989).

The necessity to develop special strains of bacteria which possess both high metal and temperature tolerance and better leaching capability thus becomes clearly evident. Genetic engineering can play a significant role in this direction. One of the primary objectives of genetic manipulation is to develop techniques to introduce the desired characteristics into the leaching bacteria. Genetic aspects of Thiobacillus ferrooxidans are not well understood. Methods need to be developed for introducing desirable genetic information into the bacterium. Attempts have already been made to detect plasmids, their analysis and to evaluate the possibilities of cloning them into $E$. coli vectors. Data about the presence of plasmid DNA in Thiobacillus ferrooxidans are being generated and methods for plasmid isolation and identification worked out. The presence of multiple plasmids in a uranium-resistant strain of Thiobacillus ferrooxidans has been demonstrated and a recombinant plasmid successfully obtained by 
cloning a $6.7 \mathrm{~kb}$ plasmid of Thiobacillus ferrooxidans into the $E$. coli vector. Similarly, cloning from an arsenic-resistant strain has been attempted. It has also been suggested that plasmid DNA could be responsible for metal resistance to Thiobacilli. Metal resistance can be plasmid-mediated.

Microorganisms may thus be genetically engineered by transferring plasmids. The coding genes can be cut off from one plasmid by restriction enzymes, sorted and inserted into a vector plasmid by enzymatic action. This recombinant DNA could be introduced into a host cell for cloning. Possibilities of developing genetically manipulated super strains of Thiobacillus ferrooxidans thus exist.

\section{References}

Attia Y A and Elzeky M 1989 Hydrometallurgy 22291

BIOMINE 1993 International Conference and Workshop on Applications of Biotechnology to the Minerals Industry (Australian Mineral Foundation, Glenside, Australia)

Brad Merchant P 1986 Fundamental and applied biohydrometallurgy (eds) R W Lawrence, R M R Branion and H G Ebner (Amsterdam: Elsevier) 53

Hackl R P and Wright F R 1989 Biohydrometallurgy (eds) J Salley, R G C McCready and P L Wichlacz (Ottawa, Canada: CANMET) p. 533

Hutchins S R, Brierley J A and Brierley C A 1988 Mining Eng. 40249

Karavaiko G I and Groudev S N 1985 Modern aspects of microbiological hydrometallurgy (Moscow: GKNT)

Komnitsas C and Pooley F D 1990 Miner. Eng. 3295

Lawrence R W 1990 Microbial mineral recovery (eds) H L Ehrlich and C Brierley (New York: McGraw Hill) Natarajan K A 1992 Miner. Proces. Extract. Metall. Rev. 8143

Torma A E 1992 Interdis. Sci. Rev. 17366 